\title{
Complete Genome Sequence of Strain WHRI 3811 Race 1 of Xanthomonas campestris pv. campestris, the Causal Agent of Black Rot of Cruciferous Vegetables
}

\author{
Congcong Kong, ${ }^{1}$ Vânia Horta de Passo, ${ }^{2}$ Zhiyuan Fang, ${ }^{1}$ Limei Yang, ${ }^{1}$ Mu Zhuang, ${ }^{1}$ Yangyong \\ Zhang, ${ }^{1}$ Yong Wang, ${ }^{1}$ Joana G. Vicente, ${ }^{2, \dagger}$ and Honghao Lv ${ }^{1, \dagger}$ \\ ${ }^{1}$ Institute of Vegetables and Flowers, Chinese Academy of Agricultural Sciences; Key Laboratory of \\ Biology and Genetic Improvement of Horticultural Crops, Ministry of Agriculture, Beijing 100081, China \\ ${ }^{2}$ School of Life Sciences, University of Warwick, Wellesbourne Campus, Warwick CV35 9EF, U.K.
}

\begin{abstract}
Xanthomonas campestris pv. campestris is an important bacterial pathogen that causes black rot and brings about enormous production loss for cruciferous vegetables worldwide. Currently, genome sequences for only a few $X$. campestris pv. campestris isolates are available, most of which are draft sequences. Based on the next-generation sequencing and single-molecule sequencing in real time technologies, we present here the complete genome sequence of strain WHRI 3811 race 1 of $X$. campestris pv. campestris, which is a type strain that has been extensively used. The genome data will contribute to our understanding of $X$. campestris pv. campestris genomic features and pave the way for research on $X$. campestris pv. campestris-host interactions.
\end{abstract}

Xanthomonas campestris, a member of the bacterial genus Xanthomonas, ranks as high as fifth in all the bacterial plant pathogens, based on their scientific and economic importance (Mansfield et al. 2012). X. campestris pv. campestris is the causal agent of black rot of many cruciferous crops, including cabbage, broccoli, cauliflower , and Chinese cabbage, and has caused considerable production losses worldwide every year (Hayward 1993; Vauterin et al. 1990; Vicente and Holub 2013).

Black rot caused by $X$. campestris pv. campestris was first described as a disease of cabbage in the United States and has now been found almost all over the world, whereever crucifers are grown (Garman 1894; Jensen et al. 2010; Vicente et al. 2001; Williams 1980). Until now, 11 races have been identified using differential hosts and molecular ways, with race 1 and 4 being most prevalent worldwide (Cruz et al. 2017; Fargier and Manceau 2007; Rouhrazi and Khodakaramian 2014; Singh et al. 2016; Vicente et al. 2001). Currently, genome sequences from only a few isolates with limited origins for races 1,3,4, and 9 are available, most of which are draft sequences (Bolot et al. 2015; da Silva et al. 2002; Desai et al. 2015; Horta de Passo 2016; Qian et al. 2005; Vorhölter et al. 2008).

Additional genome sequences for various $X$. campestris pv. campestris isolates will contribute to our knowledge of $X$. campestris pv. campestris genomic diversity. Here, the $X$. campestris pv. campestris strain WHRI 3811 (PHW 1205) race 1, isolated in the United States from Brassica oleracea, which has been widely used in previous studies as a type strain (Taylor et al. 2002; Vicente et al. 2001), was subjected to whole-genome sequencing. The pathogen was incubated on nutrient broth medium and genomic DNA was extracted with

${ }^{\dagger}$ Corresponding authors: H. Lv; Ivhonghao@ @aas.cn and J. G. Vicente; Joana.Vicente@ warwick.ac.uk. The author(s) declare no conflict of interest.

Accepted for publication 6 August 2019.

(c) 2019 The American Phytopathological Society

\section{Funding}

This work was financially supported by grants from the National Key Research and Development Program of China (2017YFD0101804), the Central Public-interest Scientific Institution Basal Research Fund (Y2018YJ04) and the Science and Technology Innovation Program of the Chinese Academy of Agricultural Sciences (CAAS-ASTIP-IVFCAAS).

Keywords

bacterial pathogenesis, genomics 
the DNeasy blood and tissue kit (Qiagen Inc., Shanghai, China). To obtain the complete genome, two libraries were constructed: $20 \mathrm{~K}$ of the single-molecule sequencing in real time (SMRT) library, specifying standard sequencing mode with insert size of $20 \mathrm{~kb}$ under the platform of PacBio (Pacific Biosciences Inc., Menlo Park, CA, U.S.A.), and PE400 of the nextgeneration sequencing (NGS) library, specifying a $2 \times 251$ bp paired-end with an insert size of $400 \mathrm{bp}$ under the platform of Illumina Miseq (Illumina Inc., San Diego, CA, U.S.A.).

De novo assembling and annotation procedures included the following. i) For assembly of the NGS data, a total of 7,577,892 reads totaling 2.13-Gb bases were generated, using the Miseq platform. After data quality control and trimming, the high-quality data of 7,520,546 reads totaling 1.92-Gb bases were obtained and assembled to NGS scaffolds and contigs, using the software A5-miseq v20150522 (Coil et al. 2015) and SPAdes v3.9.0 (Bankevich et al. 2012). ii) For assembly of the SMRT data, a total of 94,617 sequences totaling $0.89-\mathrm{Gb}$ bases were generated, using the PacBio platform, and were then assembled to SMRT scaffolds and contigs, using the tool Canu v1.4 (Koren et al. 2017). iii) For mix assembly, the NGS and SMRT data were assembled together to NGS-SMRT scaffolds and contigs, using SPAdes v3.9.0 (Bankevich et al. 2012). iv) For final assembly, all the scaffolds and contigs were aligned and assembled together, using MUMmer v3.1 (Kurtz et al. 2004), and the final assembly was confirmed using Pilon v1.18 (Walker et al. 2014). v) For annotation, GLIMMER 3.0 (Delcher et al. 1999), tRNAscan-SE v1.3.1 (Lowe and Eddy 1997), and RNAmmer v1.2 (Lagesen et al. 2007) were used for coding and noncoding gene prediction.

The final assembly of the chromosome genome was 5,072,566 bp in length, with 0 gaps and a GC content of $65.1 \%$. There were, in total, 4,661 protein-coding genes, six ribosomal RNA genes, 53 transfer RNA genes, and 131 other noncoding RNA genes. In addition, one plasmid comprised 39,063 bp with GC content of $62.4 \%$ and 50 protein-coding genes. So far, complete genomes of three $X$. campestris pv. campestris strains have been sequenced, including ATCC 33913 (race 3) (da Silva et al. 2002), 8004 (race 9) (Qian et al. 2005), and B100 (race 1) (Vorhölter et al. 2008). The lengths of these genomes were 5,076,1875, $5,148,708$, and 5,079,002 bp, respectively, harboring 4,181, 4,273, and 4,471 protein-coding genes, respectively. Compared with them, the number of predicted protein-coding genes was the largest in WHRI 3811 and only WHRI 3811 had one plasmid. These genomic data will contribute to our understanding of $X$. campestris pv. campestris genomic variation, $X$. campestris pv. campestris-host interactions, and, ultimately, will be useful for the development of strategies to prevent and control this disease.

This whole-genome shotgun project has been deposited in the GenBank database under accession number CP025750.

\section{Acknowledgments}

This work was completed in the Key Laboratory of Biology and Genetic Improvement of Horticultural Crops, Ministry of Agriculture, Beijing 100081, China.

\section{Literature Cited}

Bankevich, A., Nurk, S., Antipov, D., Gurevich, A. A., Dvorkin, M., Kulikov, A. S., Lesin, V. M., Nikolenko, S. I., Pham, S., Prjibelski, A. D., Pyshkin, A. V., Sirotkin, A. V., Vyahhi, N., Tesler, G., Alekseyev, M. A., and Pevzner, P. A. 2012. SPAdes: A new genome assembly algorithm and its applications to single-cell sequencing. J. Comput. Biol. 19:455-477.

Bolot, S., Cerutti, A., Carrère, S., Arlat, M., Fischer-Le Saux, M., Portier, P., Poussier, S., Jacques, M. A., and Noël, L. D. 2015. Genome sequences of the race 1 and race 4 Xanthomonas campestris pv. campestris strains CFBP 1869 and CFBP 5817. Genome Announc. 3:e01023-15.

Coil, D., Jospin, G., and Darling, A. E. 2015. A5-miseq: An updated pipeline to assemble microbial genomes from Illumina MiSeq data. Bioinformatics 31: 587-589.

Cruz, J., Tenreiro, R., and Cruz, L. 2017. Assessment of diversity of Xanthomonas campestris affecting cruciferous plants in Portugal and disclosure of two novel $X$. campestris pv. campestris races. J. Plant Pathol. 99:403-414.

da Silva, A. C., Ferro, J. A., Reinach, F. C., Farah, C. S., Furlan, L. R., Quaggio, R. B., Monteiro-Vitorello, C. B., Van Sluys, M. A., Almeida, N. F., Alves, L. M., do
Amaral, A. M., Bertolini, M. C., Camargo, L. E., Camarotte, G., Cannavan, F., Cardozo, J., Chambergo, F., Ciapina, L. P., Cicarelli, R. M., Coutinho, L. L., Cursino-Santos, J. R., El-Dorry, H., Faria, J. B., Ferreira, A. J., Ferreira, R. C., Ferro, M. I., Formighieri, E. F., Franco, M. C., Greggio, C. C., Gruber, A., Katsuyama, A. M., Kishi, L. T., Leite, R. P., Lemos, E. G., Lemos, M. V., Locali, E. C., Machado, M. A., Madeira, A. M., Martinez-Rossi, N. M., Martins, E. C., Meidanis, J., Menck, C. F., Miyaki, C. Y., Moon, D. H., Moreira, L. M., Novo, M. T., Okura, V. K., Oliveira, M. C., Oliveira, V. R., Pereira, H. A., Rossi, A., Sena, J. A., Silva, C., de Souza, R. F., Spinola, L. A., Takita, M. A., Tamura, R. E., Teixeira, E. C., Tezza, R. I., Trindade dos Santos, M., Truffi, D., Tsai, S. M., White, F. F., Setubal, J. C., and Kitajima, J. P. 2002. Comparison of the genomes of two Xanthomonas pathogens with differing host specificities. Nature 417:459-463.

Delcher, A. L., Harmon, D., Kasif, S., White, O., and Salzberg, S. L. 1999. Improved microbial gene identification with GLIMMER. Nucleic Acids Res. 27:4636-4641.

Desai, D., Li, J. H., van Zijll de Jong, E., Braun, R., Pitman, A., Visnovsky, S., Hampton, J., and Christey, M. 2015. Draft genome sequences of two New Zealand Xanthomonas campestris pv. campestris isolates, ICMP 4013 and ICMP 21080. Genome Announc. 3:e01247-15. 
Fargier, E., and Manceau, C. 2007. Pathogenicity assays restrict the species Xanthomonas campestris into three pathovars and reveal nine races within $X$. campestris pv. campestris. Plant Pathol. 56:805-818.

Garman, H. 1894. A bacterial disease of cabbage. Kentucky Agricultural Experiment Station Rep. 3:43-46.

Hayward, A. C. 1993. The hosts of Xanthomonas. Pages 1-119 in: Xanthomonas. Swings, J. G., and Civerolo, E. L., eds. Chapman \& Hall, London.

Horta de Passo, V. 2016. Molecular genetics of interactions between Xanthomonas campestris pv. raphani and Arabidopsis thaliana. Ph.D. thesis. University of Warwick, Warwick, U.K.

Jensen, B. D., Vicente, J. G., Manandhar, H. K., and Roberts, S. J. 2010. Occurrence and diversity of Xanthomonas campestris pv. campestris in vegetable brassica fields in Nepal. Plant Dis. 94:298-305.

Koren, S., Walenz, B. P., Berlin, K., Miller, J. R., Bergman, N. H., and Phillippy, A. M. 2017. Canu: Scalable and accurate long-read assembly via adaptive $k$-mer weighting and repeat separation. Genome Res. 27:722-736.

Kurtz, S., Phillippy, A., Delcher, A. L., Smoot, M., Shumway, M., Antonescu, C., and Salzberg, S. L. 2004. Versatile and open software for comparing large genomes. Genome Biol. 5:R12.

Lagesen, K., Hallin, P., Rødland, E. A., Staerfeldt, H. H., Rognes, T., and Ussery, D. W. 2007. RNAmmer: Consistent and rapid annotation of ribosomal RNA genes. Nucleic Acids Res. 35:3100-3108.

Lowe, T. M., and Eddy, S. R. 1997. tRNAscan-SE: A program for improved detection of transfer RNA genes in genomic sequence. Nucleic Acids Res. 25:955-964.

Mansfield, J., Genin, S., Magori, S., Citovsky, V., Sriariyanum, M., Ronald, P., Dow, M., Verdier, V., Beer, S. V., Machado, M. A., Toth, I., Salmond, G., and Foster, G. D. 2012. Top 10 plant pathogenic bacteria in molecular plant pathology. Mol. Plant Pathol. 13:614-629.

Qian, W., Jia, Y., Ren, S. X., He, Y. Q., Feng, J. X., Lu, L. F., Sun, Q., Ying, G., Tang, D. J., Tang, H., Wu, W., Hao, P., Wang, L., Jiang, B. L., Zeng, S., Gu, W. Y., Lu, G., Rong, L., Tian, Y., Yao, Z., Fu, G., Chen, B., Fang, R., Qiang, B., Chen, Z., Zhao, G. P., Tang, J. L., and He, C. 2005. Comparative and functional genomic analyses of the pathogenicity of phytopathogen Xanthomonas campestris pv. campestris. Genome Res. 15:757-767.

Rouhrazi, K., and Khodakaramian, G. 2014. Genetic fingerprinting of Iranian Xanthomonas campestris pv. campestris strains inducing black rot disease of crucifers. Eur. J. Plant Pathol. 139:175-184.

Singh, D., Rathaur, P. S., Vicente, J. G., Palleroni, N. J., Hildebrand, D. C., Stead, D. E., Civerolo, E. L., Hayward, A. C., Maraite, H., Stall, R. E., Vidaver, A. K., and Bradbury, J. F. 2016. Characterization, genetic diversity and distribution of Xanthomonas campestris pv. campestris races causing black rot disease in cruciferous crops of India. Plant Pathol. 65:1411-1418.

Taylor, J. D., Conway, J., Roberts, S. J., Astley, D., and Vicente, J. G. 2002. Sources and Origin of Resistance to Xanthomonas campestris pv. campestris in Brassica Genomes. Phytopathology 92:105-111.

Vauterin, L., Swings, J., Kersters, K., Gillis, M., Mew, T. W., and Schroth, M. N. 1990. Towards an improved taxonomy of Xanthomonas. Int. J. Syst. Bacteriol. 40:312-316.

Vicente, J. G., Conway, J., Roberts, S. J., and Taylor, J. D. 2001. Identification and origin of Xanthomonas campestris pv. campestris races and related pathovars. Phytopathology 91:492-499.

Vicente, J. G., and Holub, E. B. 2013. Xanthomonas campestris pv. campestris (cause of black rot of crucifers) in the genomic era is still a worldwide threat to brassica crops. Mol. Plant Pathol. 14:2-18.

Vorhölter, F. J., Schneiker, S., Goesmann, A., Krause, L., Bekel, T., Kaiser, O., Linke, B., Patschkowski, T., Rückert, C., Schmid, J., Sidhu, V. K., Sieber, V., Tauch, A., Watt, S. A., Weisshaar, B., Becker, A., Niehaus, K., and Pühler, A. 2008. The genome of Xanthomonas campestris pv. campestris B100 and its use for the reconstruction of metabolic pathways involved in xanthan biosynthesis. J. Biotechnol. 134:33-45.

Walker, B. J., Abeel, T., Shea, T., Priest, M., Abouelliel, A., Sakthikumar, S., Cuomo, C. A., Zeng, Q., Wortman, J., Young, S. K., and Earl, A. M. 2014. Pilon: An integrated tool for comprehensive microbial variant detection and genome assembly improvement. PLoS One 9:e112963.

Williams, P. H. 1980. Black rot: A continuing threat to world crucifers. Plant Dis. 64 : 736-742. 